Transnational Pride, Global Closets and Regional Formations of Screen Activism: Documentary LGBTQ Narratives from Turkey

\title{
Cüneyt Çakırlar
}

Nottingham Trent University, United Kingdom

cuneyt.cakirlar@ntu.ac.uk

\begin{abstract}
This study explores three documentary projects from Turkey, namely Proudly Trans in Turkey (by Gabrielle Le Roux, 2012), My Child (by Can Candan, 2013), and Trans X Istanbul (by Maria Binder, 2014). Attempting to make visible various spaces and formations of LGBTQ activism in Turkey, these collaborative projects can be considered as practices of screen activism that critically reflect on their own circulation, spectatorial address, ethnographic accent, and documentary aesthetic. Attempting to contest modes of the transnational gaze which reifies the saviour discourses of the Gay International and its globalised imperatives of liberation and pride, this discussion examines the extent to which the regional complexities of intersectional LGBTQ activism are compromised by the investment in these activist subjects' global humanitarian value and international intelligibility. Questioning the ways in which these documentaries tackle their spectatorial address as well as the global and
\end{abstract}


local complexities of sexual politics, this study aims to demonstrate how various forms/styles of documentary could contest, negotiate, and reinvent a transnational gaze that critically engages with the ethnographic constructions of sexuality, community, identity, and nation.

Keywords: documentary; ethnography; LGBTQ activism; Turkey; transnationalism; artivism

The recent turns of events in global sexual politics in various international frameworks of human rights activism, and the increased attention given to LGBTQ studies in various transregional networks of academia, have complicated the universalizing debates addressing cultures and categories of sexual identity/identification. Rendering visible the complex geopolitical, multi-scalar dynamics of sexual politics, the new formations of LGBTQ cultures in the non-Western world trigger an urgency to address the voices of regional actors by rethinking the epistemologies of sexual subjectivity within intersectional frameworks. What makes LGBTQ documentary filmmaking a crucial field of knowledge production is this urgency to encourage communities to produce alternative truths that would critically respond to neo-colonial ideologies appropriating sexuality as a political instrument for "democratizing" and "civilizing" certain nations or regions (Haritaworn 2015; Massad 2002).

Focusing on three documentary projects, namely Trans X Istanbul (Binder 2014), Proudly Trans in Turkey (Le Roux 2012), and My Child (Candan 2013), this study explores the ways in which discourses of affirmation and 
empowerment are appropriated in the practices of LGBTQ documentary filmmaking from Turkey. These documentaries focus on an Islamicate and precariously secular national context. The regional actors on screen defend an inclusive and dissident queer politics that does not prioritize an agenda shaped by faith as the primary marker of LGBTQ identity and community. Attempting to make visible various spaces and formations of LGBTQ activism in Turkey, these collaborative projects can be considered as practices of screen activism which critically reflect on their own circulation, spectatorial address, ethnographic accent, and documentary aesthetic. Attempting to prioritise a focus on the regional complexities of intersectional queer activism, these documentaries seem to contest and negotiate transnational discourses of LGBTQ identities that reify the globalized imperatives of liberation, pride, and humanitarian intervention. The critical regionalism at work in these projects, however, neither fetishizes its national/ethnic referent nor constructs a radical alterity by enacting a "third eye" through its ethnographic gaze (Rony 1996). Exposing the spectator to intersectional LGBTQ politics and its actors, these works treat their subjects as active interlocutors of community and as performers of ethnographic knowledge.

Through an analysis of these three documentaries, this study proposes a discussion of the ways in which various transnational registers of LGBTQ documentary production engage with the ethnographic site, the regional context, and the narrative framing of sexual subjectivity on screen. Hence, the selection of these three films relies on their shared transnational production context - in terms of both spectatorial address and funding. 
Although the low-budget, regionally circulated, activist productions of earlier LGBTQ documentaries from Turkey - such as Aykut Atasay's Yürüyoruz (We're Marching, 2006), Travestiler (Transvestites, 2007), and Beyaz Atlı Prens Boşuna Gelme! (Prince Charming Don’t Bother to Come, 2009), as well as Melisa Önel's Ben ve Nuri Bala (Me and Nuri Bala, 2009) - could contribute to this discussion in productive ways, this paper capitalises upon the more recent transnational productions and their logic of regionality. Therefore, the films selected here not only demonstrate effectively the ideological operation of such global production registers, but also facilitate a wider critical debate on the increasingly globalised discourses of intersectional LGBTQ activism in Turkey.

\section{Ethics of collaboration in Maria Binder's Trans $X$ Istanbul (2014)}

In her critical examination of the "documentary logic of sobriety," Pooja Rangan takes into account a particular mode of humanitarian "seriousness" in ethnographic filmmaking, where the discourse of sobriety operates "not merely as an ideological ruse but as the symptom and mandate of a humanitarian ethical paradigm — one in which the urgent, immediate task of saving human lives legitimates and even actively defers all other considerations, including the aesthetics and politics of representation" (2014, 2; see also Bandi 2016). Resonating with Rangan's critique of humanitarian intervention and the ethnographic/documentary gaze it produces, Hart and Dillwood's reading of Call Me Kuchu (2012), a documentary focusing on the struggle of 
Ugandan LGBTQ activists with anti-homosexuality legislation, proposes a critical mode of analysis that prioritizes an interrogation of the ways in which the film's humanitarian discourse engages with "time, contact, context and scale" $(2015,1012)$. Treating Call Me Kuchu as "a dynamic artefact of transnational and post-colonial contexts" $(2015,1009)$, these scholars argue that the formal and narrative choices in the film fail to provide depth in terms of how the regional actors of LGBTQ activism engage with the local specificities of sexual politics. This critical evaluation can also be taken as a wider critique of the genre of rightsbased documentary filmmaking and its neoliberal logic of transnational humanitarianism (see, for example, Bandi 2016), which, in the case of Call Me Kuchu, "underscores the potential to misread the social and political oppression their subjects experience as symptomatic of a globally undifferentiated homophobia" (Hart and Dillwood 2015, 1020). Being critically attentive to the ideological risks of rights-based documentary filmmaking in obscuring relations of "time, contact, context and scale" (Hart and Dillwood 2015, 1012), my discussion of Maria Binder's Trans X Istanbul (2014) and Gabrielle Le Roux's Proudly Trans in Turkey (2012) explores how these documentary projects give an account of their own ethnographic gaze and collaborative approach.

Maria Binder's Trans X Istanbul focuses on the life of Ebru Kiranc1, an Istanbul-based trans activist. Through Ebru's eyes, the documentary aims to explore the trans community's struggle with hate crimes, urban segregation, and the exclusionary practices of urban regeneration projects in Istanbul. This exploration incorporates multiple modes of 
representation in documentary filmmaking, as identified by Nichols: expository, observational, interactive, and reflexive modes (1992, 32). The combined framework enables the filmmaker to negotiate the ethical complexities of the film's transnational production context, its ethnographic focus, and the filmmaker's status as an outsider. In the introductory part of Trans $X$, Binder makes use of her footage from nine years ago (when Ebru used to do sex work to earn a living) and her voiceover in this part emphasizes how her friendship with Ebru initiated their collaboration for this film:

This is Ebru nine years ago when we first met in Istanbul. At that time, she wanted to become a politician. "Our lives aren't worth anything" she said to me. If you really want to find out, come with us. Hours later, I found myself hiding in a bush feeling very scared. But at a critical moment just when a car tried to run over three friends, I wasn't filming and Ebru cursed me. It was around this time, however, that our friendship began. [...] One day back in Berlin, I got a flood of messages that Ebru had been killed in her flat. Unable to believe it, I called her and found out that she was still alive. But one of her friends had been stabbed to death. It was then that we decided to make this film. I left Berlin and my mother joined me. We moved to Istanbul with a fully packed car to become a part of Ebru's life and her struggle. (Binder 2014)

Rather than concentrating on the scene of queer activism which Ebru is a part of, the film's primary focus is on the spatial production and structural 
operation of exclusion that trans communities experience in Istanbul. Binder seems to follow an episodic narrative in Trans $X$, where each episode focuses on a different spatial/scalar dimension of the film's subject. In the first part, the film focuses on the ways in which trans communities become precarious citizens subject to ostracization, segregation, lynching and hate crimes within the current practices of urban regeneration in Istanbul. With the guidance of Ebru, the film first documents testimonies of the trans residents of Meis Sitesi in the Avcilar district, where the conservative majority protest against trans residents and their rumoured engagement with prostitution. Binder's documentary incorporates (i) footage from news, (ii) vérité coverage of LGBT activists' public press statements, as well as Binder's footage of the anti-sex-work protests taking place in front of the apartments where the trans people reside, and (iii) talking head conversations with trans residents who have experienced various forms of violence and lynch events in the district.

Ebru acts as the leading filmic embodiment, and a catalyst, in Binder's collaborative vérité framework. Binder's use of her own reflective voiceover, which may be said to run the risk of reiterating the logic of humanitarian saviour discourses, is reciprocated by the central focus on Ebru's presence in the film-as the guiding agent and partner of collaboration. Represented as a confident, self-empowered trans activist, Ebru not only intervenes in moments of conflict to defend and support her trans friends, but also actively engages with the process of filmmaking. There are several moments in the film where Ebru, as the central figure of various activist interventions, asks Binder to shoot particular scenes of 
conflict and confrontation. Apart from the amorous relationship between them, the ongoing exchange between Ebru and Binder throughout the documentary reminds the audience of the collaborative partnership, the claim of which is, I would contend, constitutive of the film's ethical accountability. Furthermore, the fact that Ebru actively addresses Binder as the filmmaker negotiates the absence of the filmmaker's body in front of the camera, which may be taken as a potentially hegemonic, objectifying — if not colonizing — mode of authorial invisibility. Contrary to Hart and Dillwood's (2015) critique of the disembodied, non-reflective directorial discourse in Call Me Kuchu, the on-screen relational dynamic in Trans $X$, as well as the emphasis on Binder's 10-year-long friendship with Ebru, partially eliminates the ethical risks of the documentary filmmaker's relative invisibility in the film.

The film moves from the inner-district cultural conflicts and oppression that trans people face in the Avcrlar district to another territory of exclusion, displacement, and marginalisation that the community has been experiencing within the current state-led urban transformation projects in Tarlabaş1. In their study on the post-2000 shift to neoliberal governance of urban land in Turkey, Kuyucu and Ünsal provide a detailed account of the history of Tarlabaşı and how, by the mid-1990s, it "remained an innercity slum inhabited by disadvantaged transient populations," including the trans community $(2010,1488)$. The scholars note that these urban renewal initiatives "suffer from a total lack of social projects and economic programmes for the inhabitants creating a serious risk of displacement, dispossession and geographical relocation of poverty" (2010, 1491). 
Binder's Trans $X$ offers the audience intimate contact with the trans inhabitants of Tarlabaşı and with Ebru's struggle to help them negotiate eviction orders and the imposed relocation deals. Binder uses footage from radio, TV interviews, and public demonstrations, wherein Ebru—among other activists - notes that the relocation of trans people to the peripheries of the city (as part of the demographic upgrade of various locations subject to gentrification in Istanbul, including Tarlabaşı) escalates hate crimes and creates a more vulnerable community in exile. The film treats the condition of trans people as a symptom of a wider ideological continuum that produces homophobia and transphobia through hate speech, medical neglect, the non-recognition of sexual orientation as a constitutional status, the ambiguous references to "family values" and "general morality" in Turkish criminal law, and so on.

In addition to incorporating Ebru's conversations with the trans inhabitants of Avcılar and Tarlabaşı to address their precarious, economically disadvantaged situation, the film's representational discourse pays particular attention to the urban landscape. By juxtaposing the ruins of demolished buildings on various construction sites, gentrification, and renewal with a selection of conventionally exoticized, postcard-like images of Istanbul, as well as the imagined/idealized cityscapes promoted by the campaigns for urban transformation projects, Binder captures a demystified image of Istanbul which operates as a visual supplement to dramatise the structural violence and exclusion queer people face in the city. However, Binder's vérité style and her use of Ebru as informant as well as the key narrative motor enable the film to present 
an image of the city as not only a space of victimization and precarity, but also a space of dissidence and resistance.

While the first half of Trans $X$ represents Ebru as an expansive subject of activism and the "native" party of the film's collaborative narration, Binder later shifts the film's frame from the portrayal of a vulnerable queer community to Ebru's individual life story. "Underneath her lightness," Binder's voice-over notes, "Ebru allowed [her] to see her wounds: the loss of a mother who forbade her to enter the house again, the loss of a brother who threatened to kill her ..." (Binder 2014). The trip to Ebru's hometown in Zonguldak and the visit to her mother switches the focus and scale by moving the film's identity politics from a collective portrayal of the marginalized trans community in an urban sphere to an individual register of storytelling, addressing the familial exclusion and denial Ebru has experienced.

Binder's documentation of Ebru's visit to her hometown in Zonguldak and the confrontation with her mother after 30 years provides the film with a scalar dynamism rather than a narrative diversion. The film reminds the viewer of the spatiotemporal range of homophobia and transphobia, where the familial order of kinship operates as the core apparatus of oppression. Ebru's tense exchange with her mother and sister reveals their complicity in Ebru's exclusion from the family, due to their fear of Ebru's brother and the wider social pressure they internalized when coming to terms with Ebru's transgender identity. Binder's switch from the communal to the familial/individual operation of identity and body politics turns her 
portrayal of Ebru into a multi-layered representation that does not reduce the characterization of the film's central figure to an inert and personally detached native informant. Ebru becomes the actor who facilitates the scalar mobility in Binder's documentary gaze.

The final shift in the film's focus (and scale) takes place when Binder moves the focus from Ebru's hometown to the Gezi Park protests in Istanbul. A symptom of the "frustrations and tensions caused by the AKP [Justice and Development Party]-led neoliberal and neoconservative regime in Turkey," the protests started as a reaction against the urban transformation project that the government aimed to implement in the park; yet, it soon turned into a spectacle of mass dissidence where "the composition of the protestors was wildly heterogeneous" (Gambetti 2014, 92). Binder's focus on these protests and her documentation of the LGBTQ protestors' presence in this heterogeneous space of mass dissidence attempts to demonstrate the intersectional framework in which queer activism operates in Turkey. As also mentioned by Ebru in her exchange with the younger LGBTQ crowd in the park, a collective queer memory is inscribed in Gezi Park, as the park has been a place of cruising for years. Binder combines her footage of the protests with the Istanbul Pride marches of the same year. Although the footage from the Occupy Gezi protests in Binder's film seems to function as a tokenistic inclusion that ignores the inner complexities of the protests as well as the role of LGBTQ activists in the park, it effectively supplements Binder's representation of Istanbul as a site of dissidence and resistance against the city's aggressive neoliberal transformation. Ebru's exchange with 
younger trans people in Gezi park and her friendship with Didem (a young trans person who recently moved to Istanbul) provide a narrative closure that suggests the continuity of the queer struggle and the hope that it will persist across generations.

In his incisive discussion of "image ethics" in post-Stonewall lesbian and gay documentary film, Thomas Waugh suggests that a generation of lesbian and gay documentary film "past the stages of self-recognition and of self-valorisation" should prioritize "an ethical imperative [that is] the kind of self-analysis, self-criticism, self-evaluation necessary to any healthy community" $(2011,203)$. According to Waugh, "confusion over audience goals on the part of filmmakers, or the appeal to multiple or overlapping audiences" may lead lesbian and gay documentary practice to avoid presenting inner-community conflicts and to accommodate a kind of pluralism in representation $(2011,203-217)$. The transnational address in Trans $X$ accommodates a similar risk in representational ethics. Applying Waugh's critique to different geo-temporal registers of documentary representation may be ideologically problematic; however, the collaboration between Ebru and Maria Binder in Trans X Istanbul could have resolved the absence of self-analysis in the film by reflecting on the inner tensions of the trans community, and thus addressing the messiness of sexual dissidence within the local context, rather than presenting a uniform, and perhaps globally more intelligible, struggle and solidarity against transphobia. 
Documentary artivism, the politics of sampling, and strategic diversity in Gabrielle Le Roux's Proudly Trans in Turkey (2012)

In his exploration of contemporary art's relation to cultural alterity in its various ethnographic turns, Hal Foster critiques the figure of "the artist as ethnographer" and proposes a "parallactic work that attempts to frame the framer as he or she frames the other," in order to eliminate ideological patronage or a "reductive over-identification with" and "a murderous disidentification from" the other $(1996,203)$. Such a notion of a selfframing artist with a parallactic gaze should incorporate "a multiscalar consciousness that reflects on the productions and constructions of scale within the mechanism by which contemporary art's so-called internationalism produces simultaneously the (local) other and the (global) political" (Çakırlar 2013, 687). Noting the medium-specific focus of Foster's critical framework, namely site-specific installation art, George Marcus argues that the ethnographic fieldwork that film/video and theatre - as medium - could appropriate is less vulnerable to Foster's critique and "not as easily assimilated as the cultural capital of more powerful and sponsoring institutions" $(2010,87)$. In this regard, the contemporary formations of multi- and trans-media documentary practices deserve particular attention in terms of the ways in which they reconfigure art, ethnography, and screen activism, and offer an alternative to the globally hyper-commodified space of contemporary arts and its valuation of the ethnographic through the engagement with transnational capital. In this regard, practices of digital artivism, which "signifies work created by individuals who see an organic relationship between art and activism" and employs "a form of political activism that seeks egalitarian 
alliances and connections across difference [within a cross-media setting of convergence]" (Sandoval and Latorre 2008, 83), function as a contemporary mode of creative expression responding effectively to the intersections between art, ethnography, and documentary.

Gabrielle Le Roux's Proudly Trans in Turkey (2012) is a multimedia project of documentary artivism which its producers present as "a cultural intervention for social justice inspired by, created in collaboration with, and dedicated to the courage of trans and gender-variant people in Turkey and other parts of the world." Realized with the support of Istanbul LGBTT, Pembe Hayat, Amnesty International Turkey, The Human Resource Development Foundation, and the Consulate of the Netherlands, the project consists of 17 paintings and 18 videos by Le Roux, as well as transcriptions of in-depth interviews with trans and intersex people responding to open-ended, semi-structured questions on identity, sexuality, religion, and hate crimes in Turkey. This section will explore Le Roux's discourse of representation in her collaborative ethnographic approach, which Ortega identified as of "a pedagogic dispositive ... because of [the project's] mid-way position between art and activism, personal account and collective memory, and also between diverse geopolitical and intercultural contexts of production and enunciation" $(2014,88)$.

Le Roux's primary focus on trans activists in this collaborative project deserves particular attention. Rather than attempting to entirely contain the trans identity under the national referent of Turkey, the project's core 
aim is to work with activists and address their struggle by creating a horizontal ethnographic setting where Le Roux's role as artist/ethnographer is reciprocated by the activists as interlocutors of knowledge and experience, rather than objects of information and representation. In this sense, though operating within a transnational human rights framework, the project's focus on activism and its discourse of sampling prioritizes struggle and empowerment over victimhood. Rather than being framed as passive recipients of global sexual politics and its mandates of progress or liberation, the participants are presented as subjects who claim ownership of their struggle in Turkey and its regional political intricacies. Their responses to the open-ended questions shape the 18 videos, which do not necessarily reveal to the viewer a trans community with a coherent identity, but an ideologically diverse network of connectivity, solidarity, and intersectional politics. A selection of these questions are as follows:

How old are you?

How do you describe your gender identity?

How do hate crimes affect you?

Who and what qualities do you find attractive?

What is the role of religion and spirituality in your life?

What would like to share about your story?

How would you describe the state of trans people in Turkey?

What is your occupation? How does your gender affect your work?

What is your dream job?

What repressive things would you like to see changed? 
What motivated you to get involved in trans activism?

Who were your role models as youth?

What are your dreams and inspirations?

Who are your family, friends and supporters?

Why did you choose to be a part of this project and whom do you want it to reach?

What doors did your gender identity open or close for you?

(AI Turkey 2012)

The activists' responses to these questions, which are inter-cut within a talking-head format, demonstrates Le Roux's representational framework, which can be considered as a form of "strategic diversity." Not necessarily reiterating the generic register of confessional documentary, the responses used in these videos show the differences among the subjects' gender and sexual identifications, family values, faith or religious beliefs, ethnic and class backgrounds, ages, professions, political ideals, and personal aspirations. This diversity also invites the viewer to a dynamic scalar register of interpretation that shifts from personal to regional/national to global. This decolonized feminist setting of collaboration invests in the very failure of closure, and the refusal of discursive containment, the productivity of which occurs with the deliberate crossings of fiction, storytelling, and ethnography (Visweswaran 1994).

In describing their gender identity, some of the participants claim ownership of "womanhood." Others are more thorough in their descriptions of why they identify as a trans man or a trans woman. Some 
participants, however, stress the ways in which they acquire an identity as a political choice, despite their reluctance to reproduce normative gender categories. Reflecting on their sexual orientation, some participants give a clear account of their heterosexuality, while others describe their versatility in object choice or refrain from defining their orientation in a gender-specific way. In her playful response, Sema says: "I like human beings and to me there are two types of people: those who attract me and those who don't. So I'm attracted to those who attract me and I'm not attracted to those who don't attract me.” (AI Turkey 2012)

Commenting on the role of religion and spirituality in their lives, the participant activists reflect on their family backgrounds and their current approach to faith. Their backgrounds range from conservative Muslim families to more liberal/secular ones. While the majority of responses range from identification with atheism and deism to identification with Islam, most of the participants clearly state that the idea of a religion contradicts their being and their happiness. Şevval says:

The environment I grew up in wasn't religious. ... I think that religious pressure and prejudices as well as the radical belief are the grounds for a big part of the tragedy that the world sees. The traditional family structure is also nourishing a lot of bad things. Acquiring a binary gender system as well as categorizations such as black-white, good-bad, sin-moral are fruits of that. These affect us a lot. ... I identified myself as an atheist at the age of nineteen 
relying on the level of intellect I had at the time. Since then, there is no religion in my life. (AI Turkey 2012)

Some other participants, however, draw a distinction between Islam as religion and Islam as a geopolitical ideological construct. These participants express their discomfort about the ways in which Islam is experienced on a sociocultural level. Selay says:

I believe in God and Islam. I always open my hand for God and pray. I believe in our prophet. But I definitely don't believe in what they call Islam now in 2011. If this is Islam, then I am not a Muslim. Lynch, abuse, murder ... these are what's going on. But Islam is the most tolerant religion. You shall not abuse anyone, you shall not despise anyone, you shall not outcast anyone. ... This is what I know of Islam. That is the religion I believe in. (AI Turkey 2012)

A similar diversity is at work in the participants' responses to questions on the ways in which they relate to family, transnational solidarity, and work. Although the level of belonging to their biological families vary, most of the participants have a strong sense of community, friendship, and solidarity, which they prioritise as family. "What brings us together may be politics but we share an emotional bond too," says Şevval, explaining her conception of family (AI Turkey 2012). Referring to the precarity of trans people, some participants explain how they need to re-appropriate "family" and invest in alternative forms of kinship within their own 
community. However, in some interviews, the participants also demonstrate a strong sense of a transnational solidarity as a crucial part of their values of activism. "No matter where we are on this world, we TTs [transvestites and transsexuals] are the biggest family," says Belgin (AI Turkey 2012). Similarly, Sinem explains why the potential global reach of Le Roux's project matters to her:

I would like this exhibition to reach out to as many trans people as possible, and raise awareness in them about trans activism. There are about ten thousand trans people in Turkey but the activists make up to barely fifty people. ... Trans people have a fear of taking political action. ... It might be encouraging to see other trans people fighting for their rights. The murder of David Kato affects me too. I cried for him. If the struggle of a Turkish trans person can be seen somewhere in Africa, South America, or Bangladesh, the trans, the sex-workers, the human rights activists can feel a little inspiration and come out knowing there are many others like them. (AI Turkey 2012)

Talking about their occupations and professional backgrounds, the majority of participants consider sex work as an occupation which functions almost as a forced option for trans women due to the structural homophobia and transphobia in Turkey. However, in parallel to the strategic diversity Le Roux seems to target in this project, the attitudes in the participants' responses to sex work vary as well. While some participants consider sex work as the only way for them to earn a living, 
others express their sense of pride and empowerment as sex workers, and argue that it should be acknowledged, rather than stigmatized, as a form of labour. Although the majority of trans women in this project have sex work in their personal history, a fair number of them now work in human rights organizations.

The ethic of collaborative ethnography, the primary address aimed at activists, and the strategic diversity in Le Roux's artivist practice intervene in "a politics of pity ... [that] situates the sufferer as passive and the one who observes the suffering as obliged to act" (Kara and Reestorff 2015, 5). Besides the content and Le Roux's discourse of representation, the project also generates a multimedia platform. It is exhibited as an installation containing the compilation of video interviews and Le Roux's paintings of each participant. In addition, the videos have been published via the Youtube account of Amnesty International Turkey. The transcripts of the interviews (and additional materials, including the first-person story of the intersex activist Belgin and interviews with three parents of trans people) are made available in the exhibition monograph published online on the project's page on Tumblr (see Le Roux 2012).

Le Roux's portrait paintings, as part of the project, contributes to her discourse of documentary artivism which, through documenting the activists themselves, pursues a match between form and content. Le Roux incorporates a selection of the participants' own words into each painting and makes their bodies part of their own slogans, which could also be seen as an attempt to create a collaborative setting in the process of portraiture. 
Refusing to position herself as an artist who "gives voice to and empowers people whose voices are not heard" (Le Roux and Şeker 2013, 259; my translation), Le Roux notes that her choice to make portrait paintings as part of the stories told in the first person is a way for her to show her personal respect and admiration for the courage of people standing against prejudice and injustice (Le Roux 2012, 142).

My account of Le Roux's methodological approach in Proudly Trans in Turkey resonates considerably with Whiteman's coalition model, which proposes ways of understanding and interpreting the political impact of activist documentary films and videos. Such interpretation, according to Whiteman, must "incorporate (a) the production as well as the distribution process; (b) the full range of potential impact on producers, activist organizations, and decision makers; and (c) the efforts of social movements to create and sustain alternative spheres of public discourse" (2004, 51-52). Le Roux's collaborative ethnographic framework and multimedia approach facilitate a notion of political effect/impact that "directs our attention to the potentially important role of activist groups, initially as participants in the production process and then more importantly as catalysts in the distribution process, when documentary films become tools available to activist groups as they seek political impact" (Whiteman 2004, 51).

The ethics of collaboration, as well as the focus on activism as the primary documentary subject, in both Binder's Trans X Istanbul and Le Roux's Proudly Trans in Turkey, demonstrate critical efforts to articulate a 
discourse of representation that goes beyond the global humanitarian framings of victimhood in conventional rights-based documentaries. While these projects demonstrate powerful interventions in the hegemonic conventions of the ethnographic gaze - which appropriates others through inventing an authentic foreignness - the presentation of the cultural alterity on screen still seems to prioritize a global/transnational gaze (by critiquing it from within) rather than various modes of a local/regional gaze. Avoiding a critical look at the inner tensions and conflicts of LGBTQ activism in Turkey, these projects choose to represent a community of people whose political struggle and personal empowerment need to be acknowledged and celebrated globally. This investment in global intelligibility may be said to risk, if not dilute, the ethical accountability of its regional political impact.

\section{Coming out and instrumental parenthood in Can Candan's My Child (2013)}

The post-2000s consolidation of the LGBTQ activist movement, the increased public visibility of LGBTQ cultures, and the proliferation of discourses on gender and sexuality in contemporary Turkey could be taken as symptoms of the early, inclusive years of the AKP's (Justice and Development Party) governance and its "conservative-liberal synthesis" (Birdal 2013, 120). However, the ideological ground of the LGBT movement "significantly challenged [this synthesis] ... and reveal[ed] the fault-line between a liberal narrative based on universal human rights and democracy, and a conservative narrative based on particular values and 
identities" (Birdal 2013, 120; see also Çakırlar and Delice 2012). In his detailed analysis on the ways in which LGBTQs operate, increasingly, as the "constitutive others" of AKP's political model, Birdal argues as follows:

While politicians must respond to these demands of identity politics, they must do so without alienating and othering certain identity groups. Thus, in order to maintain social peace, conservative democracy needs to create a pluralistic political environment in which all identity groups feel mutual respect. This environment is reinforced by "national values" (milli değerler), a central pillar of Turkish conservatism. This reliance on a set of substantive values is the crux of conservative democracy's incompatibility with liberal democracy $(2013,120-1)$.

As the obsession with "national values" in Turkish politics has consistently accommodated references to "family values" and "general morals" in various legal constitutions of censorship, misogyny, and transphobia/homophobia, the formation of the voluntary support and solidarity group LISTAG (Families and Friends of LGBTIs in Turkey) facilitated an interesting platform for regional activist practice. It mobilises the parents of LGBTQ people in Turkey and subverts the conservative discourse of "family values" from within by including mothers and fathers of LGBTQ people as active collaborators of the LGBTQ movement. Can Candan's documentary My Child narrates these 
parents' own "coming out" stories_coming out as parents of LGBTQ subjects, and coming out as supporters of LGBTQ activism.

My Child has an episodic narrative structure where the choices of miseen-scène and framing, across episodes, register a sense of "coming out" in an audiovisual context. The film starts with shots of the families' living rooms - as markers of domestic family settings - where the parents tell their stories in front of the camera in a talking-head format. While giving an account of their (ethnic and sociocultural) backgrounds and their experiences as young mothers and fathers, these parents demonstrate, in their storytelling, a critical awareness of the ways in which they, from the early years of parenthood, were implicated within a patriarchal conservative national culture and its norms of gender/sexuality. Nearly half of Candan's feature contains inter-cut mid-shots of talking heads which document the parents' struggle in coming to terms with their children's sexual and/or gender identity (i.e., homosexuality and/or trans identity) and their "coming out."

The intimate "confessional" setting with talking heads then shifts to a vérité framework documenting LISTAG's social organization as a group, including group meetings, workshops with CETAD (Society for Sexual Education, Treatment and Research), dinner parties, and Istanbul Pride events. In the group meeting, the members discuss issues regarding dissemination and organization, including brochures, helplines, training workshops for parents of LGBTQs, budget concerns, LISTAG's forthcoming visit to parliament, and potential international networks with 
other groups of parents. The film moves from the meeting to a workshop with CETAD, where volunteer psychiatrists provide the parents with various definitions of and distinctions between the concepts of sex, gender, and sexual orientation, and the ways in which LGBTQ subjects could be framed within these identity markers.

The film then moves to a dinner party where LGBTQ activists meet the parents and discuss various issues, including hate crimes against gay and trans people, the safety of LGBTQs in workplaces and schools, the noninclusion of sexual orientation in the constitution, anti-discrimination legislation, and the coverage of LGBTQs in the mainstream media. Next, the film shows the day of the Istanbul Pride. While preparing their banners for the pride march, parents watch the news covering their visit to parliament. This is followed by Mehmet's and Metehan's comments on the transformative power of LISTAG's presence which, through its strategic appropriation of family and parenthood, reinforces the visibility of the LGBTQ movement and its demand for rights in the mainstream public:

Instead of choosing an easier life in the society, you went there and stood in the center. Saying, "Here, we are!" That was a tremendous support. We went to the parliament, too. Nobody held our hands like that. They could do that only with a mother. (Mehmet in My Child [Candan 2013]) 
Two years ago, at the Pride March, there were two young men passing by. One said to the other: "The faggots are walking again ... Wait, look at that man's banner! It says 'my son is homosexual.' What a father! Bravo! I appreciate honesty." I saw something melt away there. The guy's discourse changed in two seconds! (Metehan in My Child [Candan 2013])

There is a performative element in the ways in which Candan deploys an audiovisual narrative trajectory throughout My Child to provide a match between the documentary form and the parents' stories of "coming out" (and of becoming activists). Starting with the mid-shots of talking heads in the intimate domestic settings of the parents' living rooms, and ending with the crane shot of the Istanbul Pride march in Taksim, My Child narrates the parents' gradually expanding relationality: the filmic form registers, in enacting, their own "coming out" story. The accelerating rhythm of the montage and the use of camera, sound, and mise-en-scène function as aesthetic tools to (i) mimic the politicized shift from the private (family/individual/closet/shame) to the public (streets/community/liberation/pride) and (ii) reflect LISTAG's urge to grow, expand, raise awareness, and create change.

In addition to the textual and formal operation of My Child as a documentary that accommodates an ethnographic drive to present a solidarity group (rather than a clearly defined community), the register of the film's production and circulation deserves particular attention in order to understand its regional political impact. The project owes its success to 
its initial crowdfunding campaign on Indiegogo, which became "a transformative apparatus in its public relations work" (Koçer 2015, 238). Comparing the project with Whiteman's coalition model, Koçer argues that My Child's crowdfunding not only paved the way for institutional donations, including those from Amnesty International, the British Embassy, and the Consulate of the Netherlands, but also "further engendered a social space that circumscribed the film's audience [who are transformed] into an active public ... through the circulation of discourse about [the film's] collective financing in social and traditional media" $(2015,240)$. This collective ownership of the project turned My Child into a political instrument for the major opposition parties: the film was screened in Ankara as part of LISTAG's visit to parliament, which enhanced the group's visibility in the media and triggered further dialogues with parents from various locations in Turkey. While the multimedia platform of artivism in Le Roux's Proudly Trans in Turkey resonates with Whiteman's coalition model through its discourse of collaboration, spectatorial access, and representational diversity, My Child accommodates further potentials of political impact: by investing in the strategic value of non-LGBTQ parents of LGBTQ people, the film's visibility in the media helped LISTAG expand its networks of parents, nationally and globally.

The ethical accountability, the documentary/ethnographic gaze, and the dynamic of identity politics in My Child do not easily compare to Trans $X$ Istanbul and Proudly Trans in Turkey, simply because Candan's film prioritises a portrayal of a group of parents rather than a particular LGBTQ 
community in Turkey. Documenting the organization of a group of "catalyst-actors" rather than the actual actors of LGBTQ activism in a particular national context, My Child (as an instrumental discursive filmic text/object) (i) bypasses the issues and risks of a unitary LGBTQ representation and its ethical accountability in a local-global framework, (ii) becomes a catalyst media form itself, and thus (iii) facilitates a potential to grow and confuse its audiences within its intersectional framework. Although it has been screened in not only particular local events in various regions of Turkey (including Ankara, Artvin, Bursa, Diyarbakır, Kayseri, Samsun, Tunceli, and Van) but also various international film festivals as well as academic events, My Child as a project has prioritized its potential community-making impact in a regional context. Rather than adapting a global discourse of LGBTQ politics into a particular regional-national context, the film's point of departure is the local. Thus, it expands from within the local, as it addresses the ways in which the regional organization of solidarity networks could result in creative intersectional discourses of queer dissidence-by politically appropriating and subverting ideologies of nation, tradition, religion, and family.

\section{Conclusion}

Through the analysis of three documentary projects, this study explores the ways in which the complex regional/local formations of sexual dissidence emerge, if not being instrumentalized, as objects of various ethnographic gazes and inquiries. Questioning the ways in which these 
documentaries tackle issues of access, political impact, spectatorial address, and the global and local complexities of sexual politics, this discussion demonstrated possible ways in which various forms/styles of documentary could contest, negotiate, and re-invent the ethnographic constructions of community and identity. Capitalising upon the geopolitics, ethics, and aesthetics of documentary mediation in regional and transnational contexts of academic/artistic production, this study explores the critical yet shifting meanings of "pride" and "empowerment" in LGBTQ documentary practice. Exposing the spectator to intersectional LGBTQ politics and its actors, the three case studies in this project provide a platform from which one could explore the limits and potentials of treating documentary subjects as active interlocutors of community and as performers of ethnographic knowledge. Binder's focus on the intersectional operations of queerness, class, and neoliberal politics of urban regeneration in Trans X Istanbul, Le Roux's ethnographic orienting of trans activism through "strategic diversity" in Proudly Trans in Turkey, and the inter-regional mobility in Candan's making of My Child as a filmic object of activism demonstrate various possibilities and political paradoxes of representing LGBTQ activism in both regional and transnational registers of documentation and address.

Nick Mai suggests that the global politics of sexual humanitarianism "recreate[s] the notion of a unified, West-centric and hierarchical humanity around essentialized and moralised understandings of secularism, gender and sexuality" $(2014,176)$. Sexual humanitarianism, according to Mai, "acts as a form of symbolic governance ... by separating 
the extreme victimhood of targeted others from a moralized, globalised and unified humanity," which "prevents [the privileged] citizens of the global North ... from reflecting on their own increasing exploitability, commodification and alienation in neoliberal times" (2014, 176-7). In this sense, the transnational LGBTQ documentaries, within their various textual, discursive, and political operations, bear contradictory ideological affinities. While these practices accommodate the potential to intervene in the global symbolic governance of sexual humanitarianism, they also run the risk of reproducing its discourse of victimhood. Schoonover and Galt open a similar critical debate that addresses queer world cinema's potential to "elaborate new accounts of the world, offering alternatives to embedded capitalist, national, hetero- and homonormative maps; revising the flows and the politics of world cinema; and forging dissident scales of affiliation, affection, affect, and form" $(2016,5)$. Resonating with this take on "queer worlding," but departing from its comparative ethic of sampling-from-the-world, this article strategically fixes the geographic reference in its sampling/exemplification and then explores the geopolitical operations of its regional/transregional documentary references in terms of affiliation, address, representation, and ethnographic framing.

\section{Acknowledgements:}

This work is dedicated to the memory of Zeliş Deniz, Boysan Yakar, and Mert Serçe, who lost their lives in a car accident in 2015. Boysan and Zeliş have been inspiring and courageous figures of LGBTQ activism in 
Turkey, whose generous and fiercely inclusive queer work gave hope and strength to many people in the queer community. I also would like to thank Maria Binder, Gabrielle Le Roux, Can Candan, Metehan Özkan, and Sema Yakar for the generous support they have offered me for this study.

\section{References}

AI (Amnesty International) Turkey/Uluslararas1 Af Örgütü Türkiye. 2012. Proudly Trans in Turkey -Trans Onurlu ve Türkiyeli. Youtube. https://www.youtube.com/playlist?list=PL2512E7325A011C0D

Bandi, S. 2016. "Sober Encounters: The Neoliberal Logics of Human Rights Documentary and Indian Feminist Documentary Filmmakers." Feminist Media Studies 16 (2): 223-238.

https://doi.org/10.1080/14680777.2015.1105839

Binder, M. dir. 2014. Trans X Istanbul. Istanbul and Berlin: Cornix Film. http://www.transxistanbul.com/

Birdal, M. S. 2013. "Queering Conservative Democracy." Turkish Politics Quarterly 11 (4): 119-129.

Çakırlar, C. 2013. "Aesthetics of Self-Scaling: Parallaxed Transregionalism and Kutluğ Ataman's Art-Practice." Critical Arts 27 (6): 684-706. https://doi.org/10.1080/02560046.2013.867591

Çakırlar, C. and S. Delice, eds. 2012. Cinsellik Muamması: Türkiye'de Queer Kültür ve Muhalefet [The Sexuality Conundrum: Queer Culture and Dissidence in Turkey]. Istanbul: Metis. 
Candan, C. dir. 2013. My Child. Istanbul: Sürela Film. http://www.mychilddocumentary.com/

Foster, H. 1996. The Return of the Real: The Avant-Garde at the End of the Century. Cambridge, MA: MIT Press.

Gambetti, Z. 2014. "Occupy Gezi as Politics of Body." In The Making of a Protest Movement in Turkey: \#Occupygezi, edited by Umut Özkırıml1, 89-102. Oxford: Palgrave-Pivot.

Haritaworn, J. 2015. Queer Lovers and Hateful Others: Regenerating Violent Times and Places. London: Pluto Press.

Hart, C., and R. Dillwood. 2015. "Call Me Kuchu: Post-colonial Dynamics in Transnational LGBT filmmaking. Feminist Media Studies 15 (6): 1009-25. https://doi.org/10.1080/14680777.2015.1008535

Kara, Selmin, and Reestorff, Camilla Møhring. 2015 "Introduction: Unruly Documentary Artivism." Studies in Documentary Film 9 (1): 1-9. https://doi.org/10.1080/17503280.2014.1002665

Koçer, S. 2015. "Social Business in Online Financing: Crowdfunding Narratives of Independent Documentary Producers in Turkey." New Media \& Society 17 (2): 231-48. https://doi.org/10.1177/1461444814558913

Kuyucu, T., and Ö. Ünsal. 2010. "Urban Transformation as State-Led Property Transfer: An Analysis of Two Cases of Urban Renewal in Istanbul." 
Urban Studies 47 (7): 1479-99.

https://doi.org/10.1177/0042098009353629

Le Roux, G. 2012. Trans, Onurlu ve Türkiyeli: Sosyal Adalet için Sanatsal Bir Müdahale [Proudly Trans in Turkey: An Artistic Intervention for Social Justice]. Istanbul: Amnesty International Turkey (also available as an open-access online source on http://transonurluveturkiyeli.tumblr.com/).

Le Roux, G., and B. Şeker. 2013. "Trans, Onurlu ve Türkiyeli: Gabrielle Le Roux ile Söyleşi.” In Başkaldıran Bedenler: Türkiye'de Transgender, Aktivism ve Altkültürel Pratikler [Revolting Bodies: Transgender Subjecitivity, Activism and Subcultural Practices in Turkey], edited by B. Şeker, 251-68. Istanbul: Metis.

Mai, N. 2014. "Between Embodied Cosmopolitism and Sexual Humanitarianism: The Fractal Mobilities and Subjectivities of Migrants Working in the Sex Industry." In Borders, Mobilities and Migrations, Perspectives from the Mediterranean in the 21st Century, edited by V. Baby-Collins, and L. Anteby-Yemini, 175-92. Brussels: Peter Lang.

Marcus, G. E. 2010. "Affinities: Fieldwork in Anthropology Today and the Ethnographic in Artwork." In Between Art and Anthropology: Contemporary Ethnographic Practice, edited by A. Schneider, and C. Wright, 83-94. Oxford and New York: Berg.

Massad, J. 2002. "Re-Orienting Desire: The Gay International and the Arab World." Public Culture 14 (2): 361-85. https://doi.org/10.1215/0899236314-2-361

Nichols, Bill. 1992. Representing Reality: Issues and Concepts in Documentary. Bloomington: Indiana University Press. 
Ortega, Abeyami. 2014. "Looking into the Eye of the Process: Intercultural Art activism, Trans*lations and Intersex/tions in the Global South." Agenda: Empowering Women for Gender Equity 28 (4): 86-93.

Rangan, P. 2014. "For a Critique of the Documentary Logic of Sobriety." World Picture 9: 1-7.

Rony, F. T. 1996. The Third Eye: Race, Cinema and Ethnographic Spectacle. Durham: Duke University Press.

Sandoval, C., and G. Latorre. 2008. "Chicana/o Artivism: Judy Baca's Digital Work with Youth of Color." In Learning Race and Ethnicity: Youth and Digital Media, edited by A. Everett, 81-108. Cambridge, MA: MIT Press.

Schoonover, K., and R. Galt. 2016. Queer Cinema in the World. Durham: Duke University Press.

Visweswaran, K. 1994. Fictions of Feminist Ethnography. Minneapolis: University of Minnesota Press.

Waugh, T. 2011. The Right to Play Oneself: Looking Back on Documentary Film. Minneapolis: University of Minnesota Press.

Whiteman, D. 2004. "Out of the Theaters and Into the Streets: A Coalition Model of the Political Impact of Documentary Film and Video." Political Communication 21 (1): 51-69. https://doi.org/10.1080/10584600490273263-1585 